J. Japan. Soc. Hort. Sci. 51(1) : 62-69. 1982.

\title{
Salt Tolerance of Green Soybeans as Affected by Various Salinities in Soil Culture ${ }^{1}$
}

\author{
Akira Nukaya, Masao Masui and Akira Ishida \\ College of Agriculture, Shizuoka University, Ohya, Shizuoka 422
}

\begin{abstract}
Summary
Green soybeans (Glycine max. Merr.) were grown in soil to determine the salt tolerance affected by salinities of sea water, $\mathrm{NaCl}, \mathrm{Na}_{2} \mathrm{SO}_{4}, \mathrm{MgCl}_{2}$ and $\mathrm{MgSO}_{4}$ at osmotic potentials of $-1.20,-1.70$ and -2.70 bars as compared to a control of -0.70 bars of base nutrient solution. Dry weight of whole plant, fresh weight of seeds and pods, and number of pods in the sea water $\left(-1.20\right.$ bars), $\mathrm{Na}_{2} \mathrm{SO}_{4}(-1.20$ and -1.70 bars) and $\mathrm{MgSO}_{4}$ (all osmotic potentials) series were not different from those in the control. Dry weight of whole plant at -2.70 bars expressed by percentage of the control was $52.6,39.6,81.5,20.4$ and $88.1 \%$ in the sea water, $\mathrm{NaCl}, \mathrm{Na}_{2} \mathrm{SO}_{4}, \mathrm{MgCl}_{2}$ and $\mathrm{MgSO}_{4}$ series, respectively. Growth in decreasing order in soil culture was $\mathrm{MgSO}_{4} \fallingdotseq \mathrm{Na}_{2} \mathrm{SO}_{4}>$ sea water $>\mathrm{NaCl}>\mathrm{MgCl}_{2}$ series. In the $\mathrm{Na}_{2} \mathrm{SO}_{4}$ and $\mathrm{MgSO}_{4}$ series, interveinal chlorosis appeared at only -1.70 bars near harvest. Chloride-salinity treatment caused chlorosis and necrosis on leaves developing acropetally at the middle stage. The plants were almost dried up at the last stage, especially at low osmotic potentials. $\mathrm{Na}, \mathrm{Mg}, \mathrm{Cl}$ and $\mathrm{SO}_{4}$ content of leaves and soil solution (SS) tended to increase with decreasing osmotic potentials of treatment solutions in sodium-, magnesium-, chloride- and sulfate-salinities, respectively. EC values of SS increased and osmotic potentials of SS decreased as osmotic potentials of treatment solutions decreased.
\end{abstract}

\section{Introduction}

Salt tolerance of green soybeans (Glycine max. Merr.) as affected by various salinities in sand culture has been reported(11). The experiment was undertaken to more adequately explain the effects of salt source and concentration on their growth and development, using single salts added to base nutrient solution. Salt tolerance of muskmelons $(9,10)$, green soybeans (5) and tomatoes (8) has been studied using diluted sea water in sand and soil cultures. With muskmelons, the whole plant dry weight as expressed by percentage of control was $56.0 \%$ in sand culture and $83.5 \%$ in soil culture at 1,000 $\mathrm{ppm} \mathrm{Cl}$. The relative fruit fresh weight at $1,000 \mathrm{ppm} \mathrm{Cl}$ was 66.2 and $70.5 \%$ in sand and soil cultures. Visible salt injury symptoms of green soybeans and tomatoes caused by diluted sea water were much more evident in sand culture than in soil culture. Relation-

\footnotetext{
1 Received for publication October 27, 1981
}

ships between salt tolerance of muskmelons and various salinities in sand and soil cultures were examined, using isosmotic potential solutions $(6,7)$. The experiment showed that visible salt injury symptoms varied with kinds of salts in sand culture, but were not observed in soil culture. The degree of growth suppression, and chemical properties of sand and soil solution also differed to some extent between sand and soil cultures.

Therefore, the present experiment was conducted to compare the effect of various salinities on salt tolerance of green soybeans in soil culture with that in sand culture at the same time and in the same greenhouse as the sand culture experiment previously reported(11).

\section{Materials and Methods}

Twenty-seven seeds of cv. 'Hakucho' were directly sown in a wooden container $(40 \times 40$ $\times 12 \mathrm{~cm}$ ) filled with 121 of Takamatsu light clay paddy soil taken at Shizuoka and mixed 
Table 1. Composition of treatment solutions and base nutrient solution.

\begin{tabular}{|c|c|c|c|c|c|c|}
\hline \multicolumn{3}{|c|}{ Treatment } & \multirow{2}{*}{$\begin{array}{l}\text { Added salt } \\
\text { concentrations }\end{array}$} & \multirow{2}{*}{$\begin{array}{c}\mathrm{EC} \\
(\mathrm{m} \mho / \mathrm{cm})\end{array}$} & \multirow{2}{*}{\multicolumn{2}{|c|}{ Composition of base nutrient solution }} \\
\hline No. & Salinities & $\pi(\text { bars })^{z}$ & & & & \\
\hline 1 & $\begin{array}{l}\text { Base nutr } \\
\text { soln }\end{array}$ & -0.70 & none & 2.43 & \multirow{10}{*}{\multicolumn{2}{|c|}{ 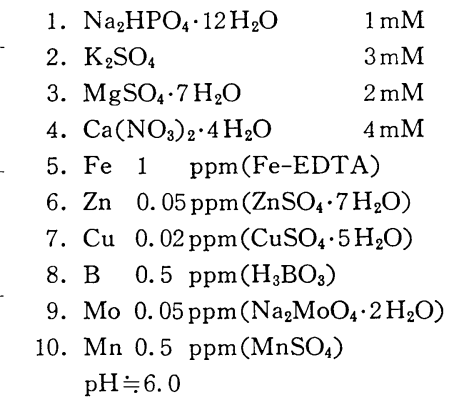 }} \\
\hline 2 & \multirow[t]{3}{*}{ Sea water ${ }^{y}$} & -1.20 & $1.9 \%$ & 3.45 & & \\
\hline 3 & & -1.70 & $3.8 \%$ & 4.50 & & \\
\hline 4 & & -2.70 & $7.6 \%$ & 6.60 & & \\
\hline 5 & \multirow[t]{3}{*}{$\mathrm{NaCl}$} & -1.20 & $687 \mathrm{mgNaCl} / 1$ & 3.38 & & \\
\hline 6 & & -1.70 & 1,374 & 4.65 & & \\
\hline 7 & & -2.70 & 2,748 & 7.05 & & \\
\hline 8 & \multirow{3}{*}{$\mathrm{Na}_{2} \mathrm{SO}_{4}$} & -1.20 & $1,261 \mathrm{mgNa}_{2} \mathrm{SO}_{4} / 1$ & 3.66 & & \\
\hline 9 & & -1.70 & 2,521 & 5.18 & & \\
\hline 10 & & -2.70 & 5,042 & 8.08 & & \\
\hline 11 & \multirow[t]{3}{*}{$\mathrm{MgCl}_{2}$} & -1.20 & $1,728 \mathrm{mgMgCl}_{2} \cdot 6 \mathrm{H}_{2} \mathrm{O} / 1$ & 3.67 & & \\
\hline 12 & & -1.70 & 3,456 & 5.24 & & \\
\hline 13 & & -2.70 & 6,912 & 8.21 & & \\
\hline 14 & \multirow[t]{3}{*}{$\mathrm{MgSO}_{4}$} & -1.20 & $3,875 \mathrm{mgMgSO}_{4} \cdot 7 \mathrm{H}_{2} \mathrm{O} / 1$ & 3.94 & & \\
\hline 15 & & -1.70 & 7,750 & 5.52 & & \\
\hline 16 & & -2.70 & 15,500 & 8.28 & & \\
\hline
\end{tabular}

${ }^{2}$ Osmotic potential. The $\pi$ of treatment solutions includes -0.70 bars of base nutrient solution.

y Sea water contains $20,500 \mathrm{ppm} \mathrm{Cl}, 10,082 \mathrm{ppm} \mathrm{Na}, 2,632 \mathrm{ppm} \mathrm{SO}_{4}, 1,262 \mathrm{ppm} \mathrm{Mg}, 445 \mathrm{ppm} \mathrm{K}$ and $393 \mathrm{ppm} \mathrm{Ca}$.

with 31 of decomposed rice straw, on April 6 , 1978. The container was placed in the greenhouse. Seedlings were thinned to 9 uniform plants per container on April 19. There were 16 treatments, as shown in Table 1, consisting of control (base nutrient solution), and sea water, $\mathrm{NaCl}, \mathrm{Na}_{2} \mathrm{SO}_{4}$, $\mathrm{MgCl}_{2}$ and $\mathrm{MgSO}_{4}$ dissolved in the base nutrient solution at osmotic potentials of $-0.50,-1.00$ and -2.00 bars. The osmotic potential of the base nutrient solution was -0.70 bars. The sea water was taken at Miho seaside. Each treatment had 4 replications, thus there was a total of 64 container plots. Treatment solutions were applied to the soil medium for 60 days from April 14 to harvest, June 12 . These applications (approximately $1 \mathrm{l} /$ container/time) were made once or twice a day whether it was cloudy or sunny. No solution was applied on rainy days. At the end of the experiment, green soybeans were separated into leaves, stem, roots, and seeds and pods. The other experimental procedures, and methods of analysis on leaves and soil solutions were the same as the sand culture experiment(11).

\section{Results}

Growth (Figs 1 and 2) At the end of the experiment, fresh weight of seeds+pods, dry weight of whole plant, leaves, stem, roots, and seeds+pods, and number of pcds tended to decrease in each salinity as osmotic potentials of treatment solutions decreased from -1.20 to -2.70 bars. However, dry weight of whole plant, leaves and stem in the control was not significantly different from that in the sea water series at -1.20 bars, in the $\mathrm{Na}_{2} \mathrm{SO}_{4}$ series at -1.20 and -1.70 bars, and in the $\mathrm{MgSO}_{4}$ series at all concentrations. Fresh weight of seeds + pods, and number of pods in the control were also not significantly different from those in the $\mathrm{NaCl}$ and $\mathrm{MgCl}_{2}$ series at -1.20 bars, in addition to above mentioned treatments. At -2.70 bars, whole plant dry weight as expressed by percentage of the conteol was $52.6,39.6$ and $20.4 \%$ in the sea water, $\mathrm{NaCl}$ and $\mathrm{MgCl}_{2}$ series, respectively. At -2.70 bars, whole plant dry weight was 81.5 and $88.1 \%$ in the $\mathrm{Na}_{2} \mathrm{SO}_{4}$ and $\mathrm{MgSO}_{4}$ series. These results showed that green soybeans were sensitive to chloride-salinity. Fresh weight 


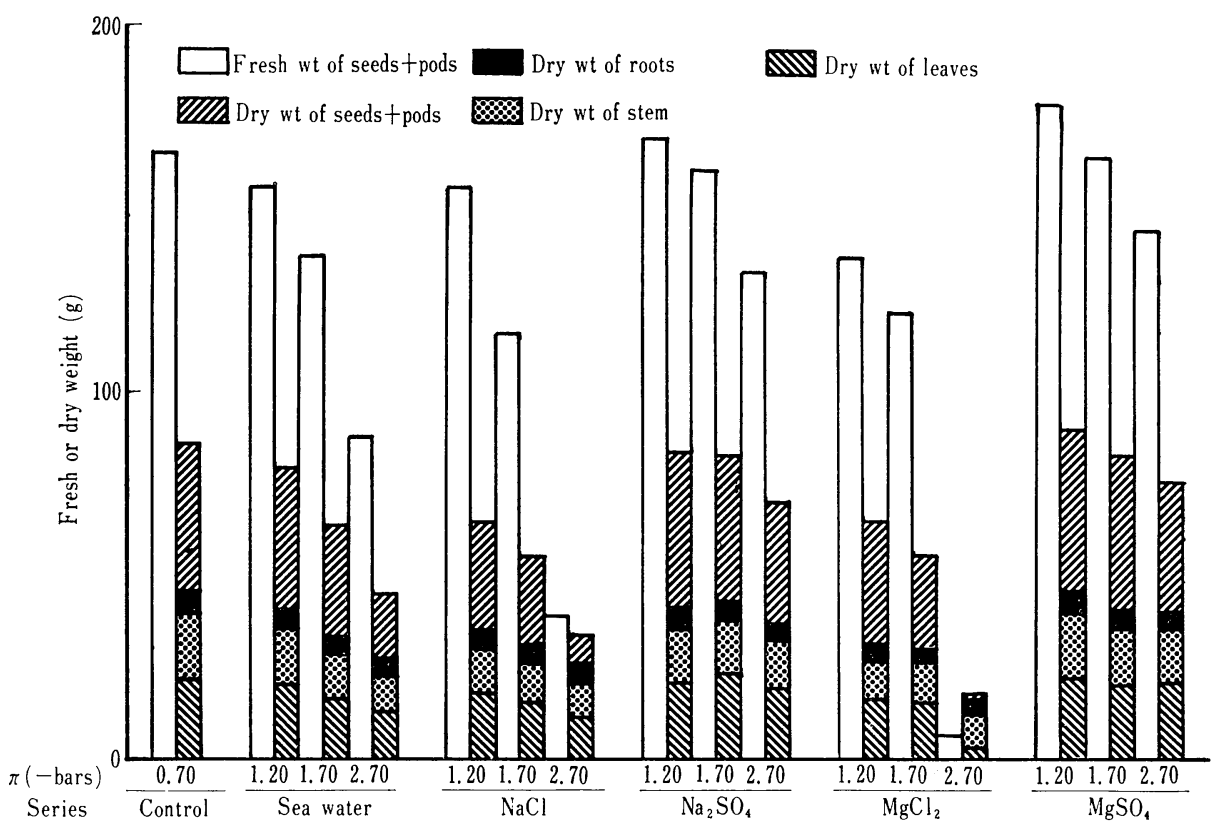

Fig. 1. Ef'ect of various salinities on fresh weight of seeds and fods, and dry weight of plant parts (average per container). Figures below columns in Figs. 1 to 3 indicate osmotic potentials (-bars) of treatment solutions.

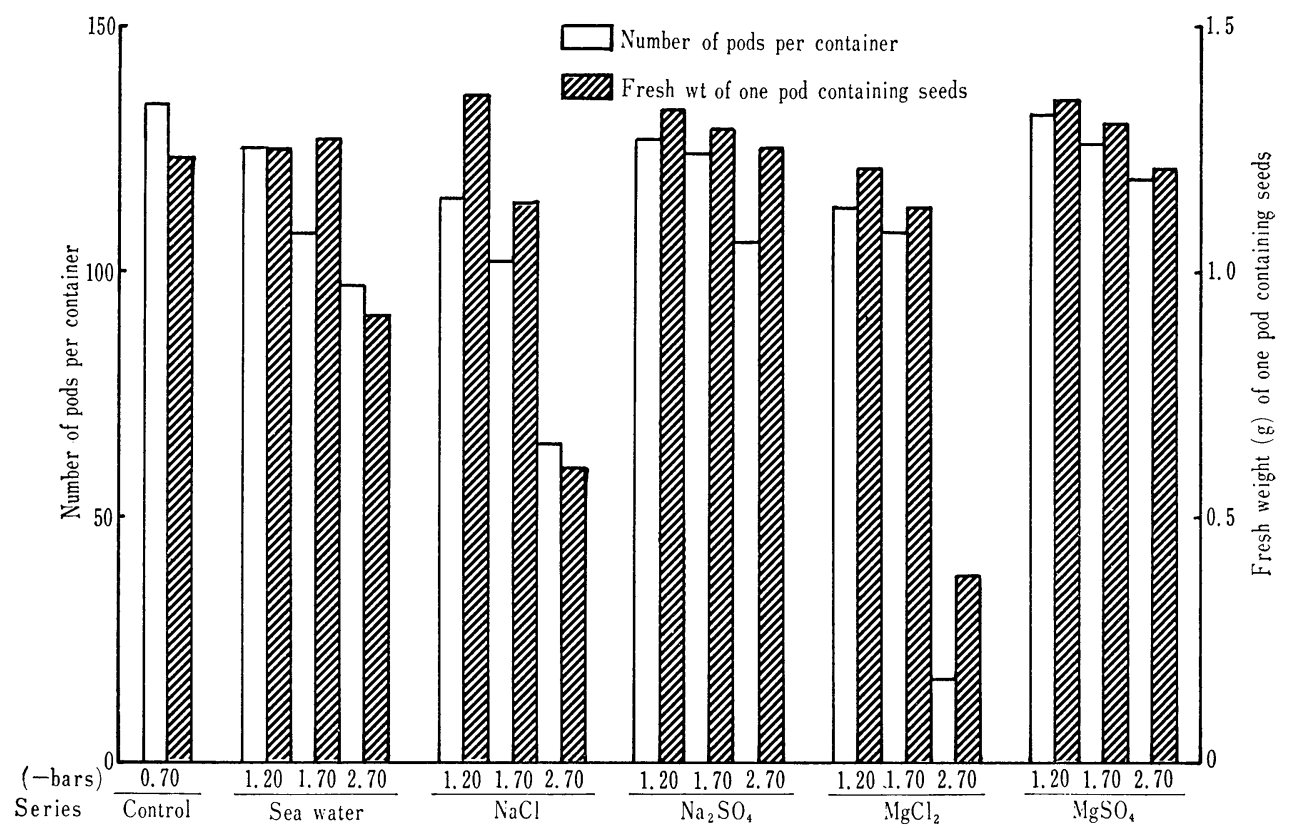

Fig. 2. Effect of various salinities on number of pods per container, and fresh weight of one pod containing seeds. 
of one pod containing seeds was markedly suppressed in the $\mathrm{NaCl}$ and $\mathrm{MgCl}_{2}$ series and almost the same as the control in the $\mathrm{Na}_{2} \mathrm{SO}_{4}$ and $\mathrm{MgSO}_{4}$ series. Based on these observations the growth was greatest in the $\mathrm{Na}_{2} \mathrm{SO}_{4}$ and $\mathrm{MgSO}_{4}$ series, followed by the sea water, and then $\mathrm{NaCl}$ series, and least in the $\mathrm{MgCl}_{2}$ series.

The salt injury symptom, chlorosis on leaves, was observed only in the sea water and $\mathrm{MgCl}_{2}$ series at -2.70 bars at the middle stage of growth and did not appear in the other treatments. At the late stage, margins of lower leaves showed chlorosis in the sea water, $\mathrm{NaCl}$ and $\mathrm{MgCl}_{2}$ series. The symptoms developed to marginal necrosis progressing acropetally. In the $\mathrm{Na}_{2} \mathrm{SO}_{4}$ and $\mathrm{MgSO}_{4}$ series, although the plants became smaller and darker green as osmotic potentials of treatment solutions decreased, visible symptoms were not observed at any osmotic potentials.

Table 2. Effect of various salinities on $\mathrm{Na}, \mathrm{Mg}, \mathrm{Cl}$ and $\mathrm{SO}_{4}$ content in leaves ( $\%$ of dry matter).

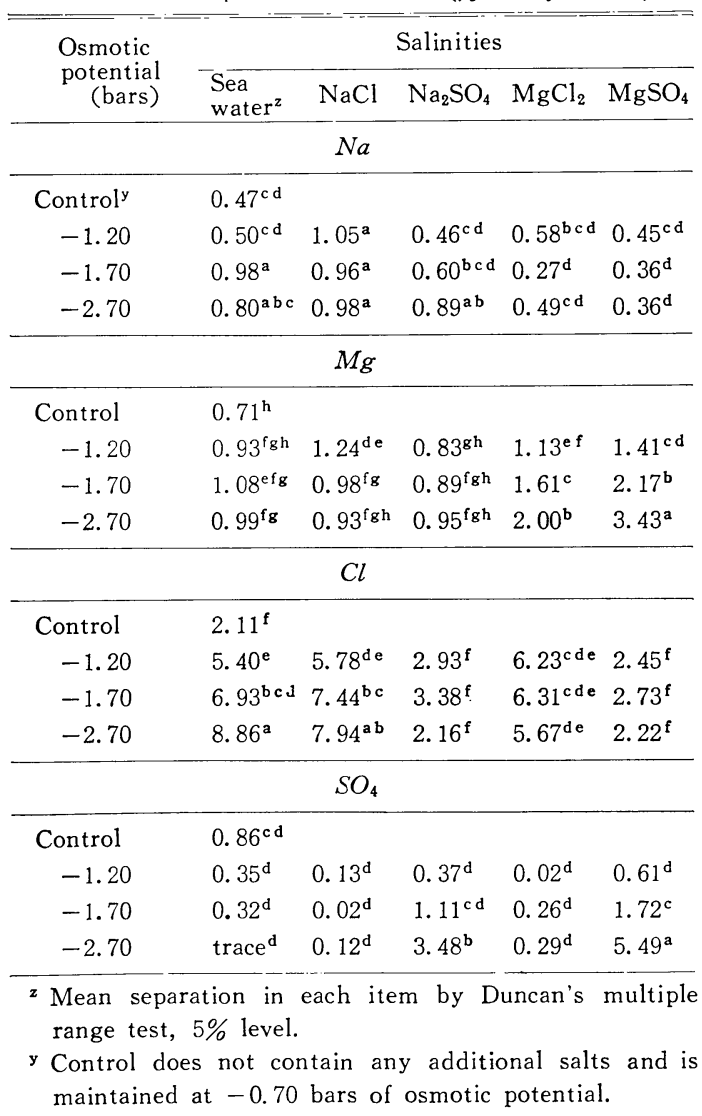

Several days before harvesting, plants were almost dried up in chloride-salinity, and interveinal chlorosis suddenly appeared in sulfate-salinity, especially in the $\mathrm{Na}_{2} \mathrm{SO}_{4}$ series at -1.70 bars.

Major elements in leaves (Tables 2 and 3) $\mathrm{Mg}$ and $\mathrm{SO}_{4}$ content in the magnesium- and sulfate-salinities increased with decreasing osmotic potentials of treatment solutions, respectively. $\mathrm{Mg}$ content was higher in the $\mathrm{MgSO}_{4}$ series (1.41 to $3.43 \%$ ) than in the $\mathrm{MgCl}_{2}$ series (1.13 to $2.00 \%$ ). Na content tended to increase in the sea water and $\mathrm{Na}_{2} \mathrm{SO}_{4}$ series as osmotic potentials of treatment solutions decreased. In the $\mathrm{NaCl}$ series, $\mathrm{Na}$ content was not significantly different ( 0.96 to $1.05 \%$ ) and higher than in the other series. $\mathrm{Cl}$ content increased in the sea water and $\mathrm{NaCl}$ series with decreasing osmotic potentials of treatment solutions, but was not significantly different in the $\mathrm{MgCl}_{2}$ series (5. 67 to $6.31 \%$ ). Ca tended to decrease in

Table 3. Effect of various salinities on total-N, P, K and $\mathrm{Ca}$ content in leaves ( $\%$ of dry matter).

\begin{tabular}{|c|c|c|c|c|c|}
\hline \multirow{2}{*}{$\begin{array}{l}\text { Osmotic } \\
\text { potential } \\
\text { (bars) }\end{array}$} & \multicolumn{5}{|c|}{ Salinities } \\
\hline & $\begin{array}{l}\text { Sea } \\
\text { water }\end{array}$ & $\mathrm{NaCl}$ & $\mathrm{Na}_{2} \mathrm{SO}_{4}$ & $\mathrm{MgCl}_{2}$ & $\mathrm{MgSO}_{4}$ \\
\hline \multicolumn{6}{|c|}{ Total-N } \\
\hline Control $^{y}$ & $2.02^{\mathrm{h}}$ & & & & \\
\hline-1.20 & $2.56^{\mathrm{g}}$ & $2.84^{\mathrm{efg}}$ & $3.11^{\mathrm{cde}}$ & $3.14^{\mathrm{cde}}$ & $3.72^{\mathrm{ab}}$ \\
\hline-1.70 & $3.00^{\text {defg }}$ & $2.65^{\mathrm{fg}}$ & $3.11^{\mathrm{cde}}$ & $3.51^{\mathrm{abc}}$ & 3. $46^{\mathrm{abcd}}$ \\
\hline-2.70 & 3. $29^{\mathrm{bcde}}$ & 3. $21^{\mathrm{cde}}$ & $3.06^{\mathrm{cdef}}$ & $3.81^{\mathrm{a}}$ & $2.58^{\mathrm{g}}$ \\
\hline \multicolumn{6}{|c|}{$P$} \\
\hline Control & $0.25^{b c}$ & & & & \\
\hline-1.20 & $0.23^{\mathrm{cd}}$ & $0.21^{\mathrm{cd}}$ & $0.23^{c d}$ & $0.22^{\mathrm{cd}}$ & $0.24^{\mathrm{bcd}}$ \\
\hline-1.70 & $0.23^{\mathrm{cd}}$ & $0.24^{\mathrm{bcd}}$ & $0.25^{\mathrm{bc}}$ & $0.24^{\mathrm{bcd}}$ & $0.23^{c d}$ \\
\hline-2.70 & $0.25^{b c}$ & $0.28^{b}$ & $0.25^{b c}$ & $0.43^{a}$ & $0.20^{\mathrm{d}}$ \\
\hline \multicolumn{6}{|c|}{$K$} \\
\hline Control & $1.25^{\mathrm{bcd}}$ & & & & \\
\hline-1.20 & 1. $25^{\mathrm{bcd}}$ & $2.20^{\mathrm{a}}$ & 1. $17^{\mathrm{cd}}$ & $2.44^{\mathrm{a}}$ & 1. $22^{b c d}$ \\
\hline-1.70 & 1. $94^{\mathrm{abc}}$ & 2. $13^{\mathrm{ab}}$ & 1. $67^{\mathrm{abc}}$ & $1.08^{\mathrm{cd}}$ & $0.68^{d}$ \\
\hline-2.70 & $1.88^{\mathrm{abc}}$ & $2.47^{\mathrm{a}}$ & $2.56^{\mathrm{a}}$ & $1.06^{\mathrm{cd}}$ & $0.67^{d}$ \\
\hline \multicolumn{6}{|c|}{$\mathrm{Ca}$} \\
\hline Control & $2.13^{\mathrm{ab}}$ & & & & \\
\hline-1.20 & $2.56^{\mathrm{a}}$ & $2.55^{\mathrm{a}}$ & $2.28^{\mathrm{ab}}$ & $2.75^{\mathrm{a}}$ & $2.35^{\mathrm{ab}}$ \\
\hline-1.70 & $2.51^{\mathrm{ab}}$ & $2.51^{\mathrm{ab}}$ & $1.94^{\mathrm{ab}}$ & $2.61^{\mathrm{a}}$ & $2.14^{\mathrm{ab}}$ \\
\hline-2.70 & $2.32^{\mathrm{ab}}$ & $2.32^{\mathrm{ab}}$ & $1.59^{a}$ & 1. $91^{\mathrm{ab}}$ & 1. $61^{b}$ \\
\hline
\end{tabular}

$z$ The same as Table 2 .

y The same as Table 2 . 
each salinity as osmotic potentials of treatment solutions decreased. $\mathrm{K}$ tended to be higher in the sodium-salinity (1.17 to $2.56 \%$ ) and lower in the magnesium-salinity $(0.67$ to $2.44 \%$ ) than in the control (1.25\%). Total-N was higher in all treatments than in the control. There seemed to be no difference in $\mathrm{P}$ content in each salinity.

Chemical properties of soil solution at the end of the experiment (Tables 4 and 5, Fig. 3) EC values increased and osmotic potentials decreased as osmotic potentials of treatment solutions decreased. At -2.70 bars $\mathrm{EC}$ values were highest in the $\mathrm{NaCl}, \mathrm{Na}_{2} \mathrm{SO}_{4}$ and $\mathrm{MgCl}_{2}$ series, followed by the sea water series, and then the $\mathrm{MgSO}_{4}$ series. $\mathrm{Mg}$, $\mathrm{Na}, \mathrm{Cl}$ and $\mathrm{SO}_{4}$ increased with decreasing osmotic potentials of treatment solutions in magnesium-, sodium-, chloride- and sulfatesalinities, respectively. $\mathrm{Mg}$ in the $\mathrm{Na}_{2} \mathrm{SO}_{4}$ series also increased with decreasing osmotic

Table 4. Effect of various salinities on $\mathrm{NO}_{3}-\mathrm{N}, \mathrm{P}, \mathrm{K}$ and $\mathrm{Ca}$ content in soil solution ${ }^{\mathrm{x}}$ at the end of the experiment.

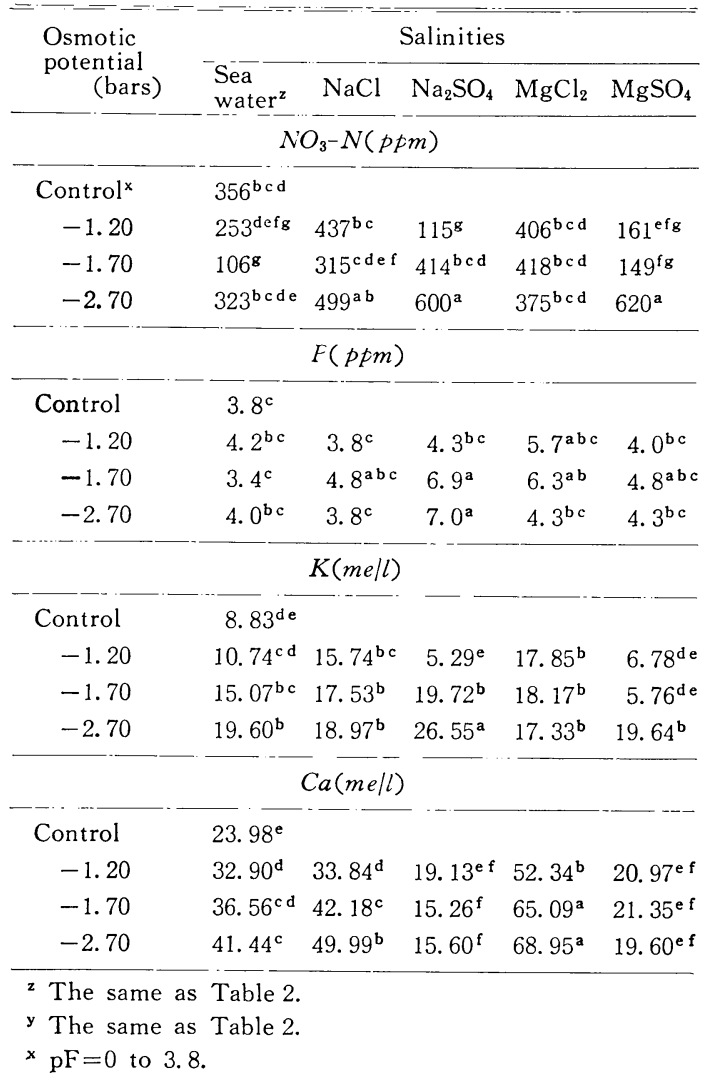

Table 5. Effect of various salinities on $\mathrm{Mg}, \mathrm{Na}, \mathrm{Cl}$ and $\mathrm{SO}_{4}$ content in soil solution ${ }^{\mathrm{x}}$ at the end of the experiment.

\begin{tabular}{|c|c|c|c|c|c|}
\hline \multirow{2}{*}{$\begin{array}{l}\text { Osmotic } \\
\text { potential } \\
\quad \text { (bars) }\end{array}$} & \multicolumn{5}{|c|}{ Salinities } \\
\hline & $\begin{array}{l}\text { Sea } \\
\text { water }\end{array}$ & $\mathrm{NaCl}$ & $\mathrm{Na}_{2} \mathrm{SO}_{4}$ & $\mathrm{MgCl}_{2}$ & $\mathrm{MgSO}_{4}$ \\
\hline \multicolumn{6}{|c|}{$M g(m e / l)$} \\
\hline Control ${ }^{y}$ & $26.58^{\text {hi }}$ & & & & \\
\hline-1.20 & 48. $49^{\mathrm{gh}}$ & $43.43^{\mathrm{ghi}}$ & $17.48^{\mathrm{i}}$ & $128.53^{\mathrm{cd}}$ & $101.97^{\mathrm{de}}$ \\
\hline-1.70 & 59. $10^{f g}$ & $50.89^{g h}$ & h $49.19^{\mathrm{gh}}$ & $223.75^{b}$ & $135.31^{c}$ \\
\hline-2.70 & $83.78^{e f}$ & $59.89^{\mathrm{fg}}$ & $69.30^{\mathrm{fg}}$ & $338.28^{a}$ & $198.24^{\mathrm{b}}$ \\
\hline \multicolumn{6}{|c|}{$\mathrm{Na}(m e \mid l)$} \\
\hline Control & $25.95^{\mathrm{hi}}$ & & & & \\
\hline-1.20 & $87.81^{\mathrm{fg}}$ & $116.42^{\mathrm{ef}}$ & $69.78^{g h}$ & $47.19^{\mathrm{hi}}$ & $19.02^{\mathrm{i}}$ \\
\hline-1.70 & $129.41^{\mathrm{e}}$ & $186.55^{d}$ & $334.90^{\mathrm{b}}$ & $36.52^{\mathrm{hi}}$ & $12.04^{\mathrm{i}}$ \\
\hline-2.70 & $222.97^{\mathrm{d}}$ & $287.12^{c}$ & $429.22^{\mathbf{a}}$ & $27.77^{\mathrm{hi}}$ & $36.97^{\mathrm{hi}}$ \\
\hline \multicolumn{6}{|c|}{$C l(p p m)$} \\
\hline Control & $738^{\mathrm{f}}$ & & & & \\
\hline-1.20 & $4281^{e}$ & $7201^{d}$ & $851^{f}$ & $7555^{\mathrm{d}}$ & $855^{f}$ \\
\hline-1.70 & $6458^{d}$ & $10203^{c}$ & $1356^{\mathrm{f}}$ & $12183^{b}$ & $624^{\mathrm{f}}$ \\
\hline-2.70 & $12274^{\mathrm{b}}$ & $15221^{\mathbf{a}}$ & $1244^{\mathrm{f}}$ & $16073^{a}$ & $1166^{\mathrm{f}}$ \\
\hline \multicolumn{6}{|c|}{$S O_{4}(p p m)$} \\
\hline Control & $2557^{\mathrm{c}}$ & & & & \\
\hline-1.20 & $2608^{c}$ & $2614^{c}$ & $4909^{c}$ & $3105^{c}$ & $6759^{c}$ \\
\hline-1.70 & $2902^{\mathrm{c}}$ & $4175^{c}$ & $17324^{\mathrm{b}}$ & $2841^{\mathrm{c}}$ & $8437^{c}$ \\
\hline-2.70 & $3125^{c}$ & $3352^{c}$ & $29560^{\mathbf{a}}$ & $3040^{c}$ & $24094^{a}$ \\
\hline
\end{tabular}

potentials. $\mathrm{Mg}$ in the $\mathrm{MgCl}_{2}$ series was higher than that in the $\mathrm{MgSO}_{4}$ series. The decreasing order of $\mathrm{Cl}$ in the chloride-salinity was the $\mathrm{MgCl}_{2}, \mathrm{NaCl}$ and sea water series. That of $\mathrm{Na}$ in the sodium-salinity was the $\mathrm{Na}_{2} \mathrm{SO}_{4}$, $\mathrm{NaCl}$ and sea water series. $\mathrm{K}$ was higher in all treatments, except for -1.20 bars in the $\mathrm{Na}_{2} \mathrm{SO}_{4}$ series and -1.20 and -1.70 bars in the $\mathrm{MgSO}_{4}$ series, than in the control. $\mathrm{Ca}$ increased in the chloride--salinity with decreasing osmotic potentials. The $\mathrm{pH}$ tended to be lower in the chloride-salinity than in the control. No definite tendency was observed in $\mathrm{NO}_{3}-\mathrm{N}$ content in each salinity.

\section{Discussion}

The results of the sand culture experiment (11) showed the growth of green soybeans was more suppressed in chloride-salinity than in sulfate-salinity. In this experiment similar results were obtained, but the degree of 


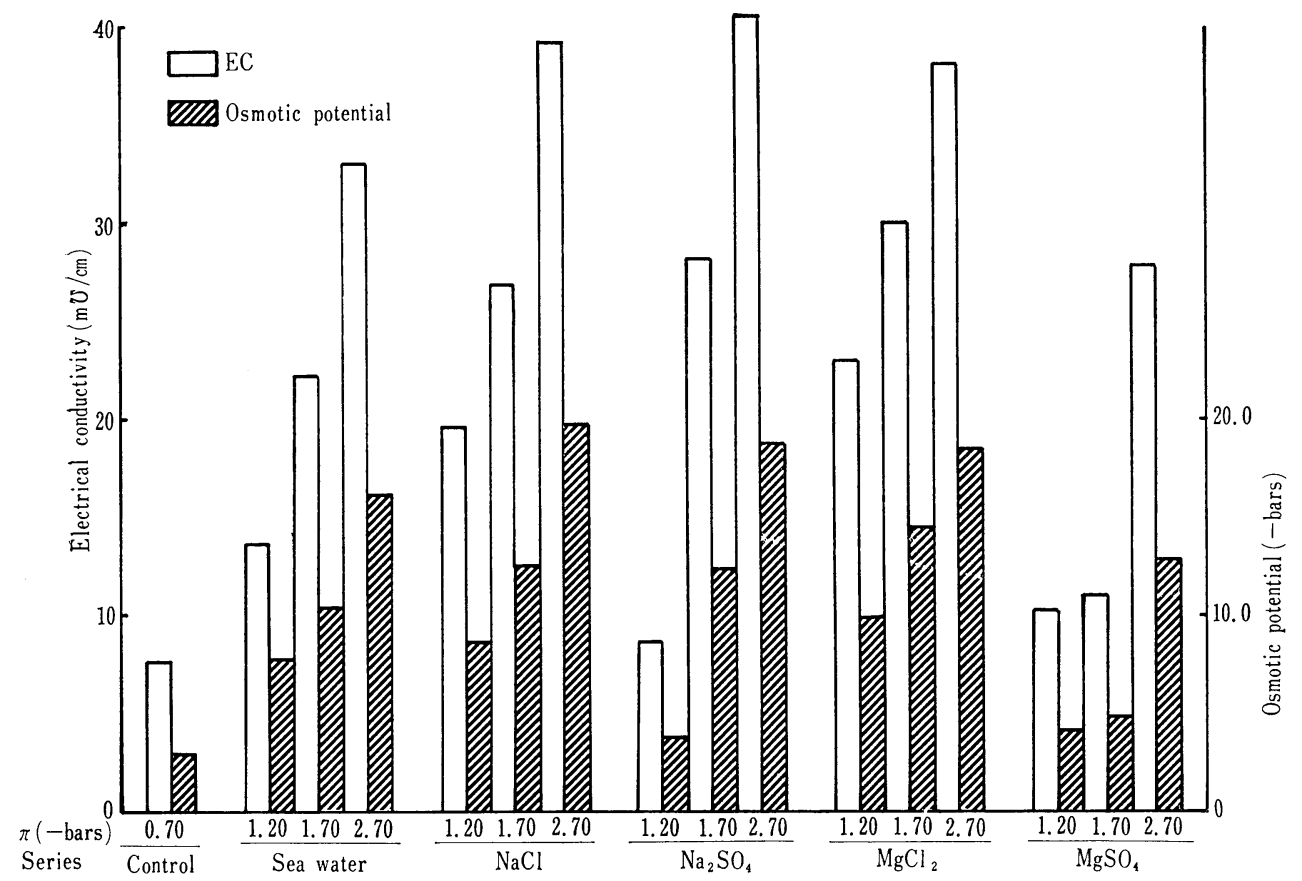

Fig. 3. Effect of various salinities on EC and osmotic potentials of soil solution at the end of the experiment.

growth suppression was to some extent different from the sand culture experiment. In soil culture green soybeans were more tolerant of salinity. For example, the osmotic potential of treatment solutions which caused a $50 \%$ loss in whole plant dry weight was calculated by graphical interpolation. It was $-1.5,-1.2,-1.5,-1.2$ and -1.8 bars in sand culture, but $-2.9,-2.3$, about $-6.0,-2.0$ and about -9.0 bars in soil culture, in the sea water, $\mathrm{NaCl}, \mathrm{Na}_{2} \mathrm{SO}_{4}$, $\mathrm{MgCl}_{2}$ and $\mathrm{MgSO}_{4}$ series, respectively. The dry weight expressed by percentage of the control was also greater in soil culture than in sand culture in each salinity. Above all, in sulfate-salinity, the growth was rarely suppressed in soil culture, and the dry weight of whole plant, fresh weight of seeds + pods, number of pods, and fresh weight of one pod containing seeds almost corresponded to the control even at -2.70 bars.

Mean $\mathrm{Cl}$ content of leaves was $6.72,7.61$ and $8.02 \%$ in sand culture, and $7.06,7.05$ and $6.07 \%$ in soil culture, in the sea water, $\mathrm{NaCl}$ and $\mathrm{MgCl}_{2}$ series, respectively. The mean $\mathrm{Cl}$ content in the $\mathrm{NaCl}$ and $\mathrm{MgCl}_{2}$ series was higher in sand culture than in soil culture. In the sea water series mean $\mathrm{Cl}$ content of leaves exclusive of -2.70 bars was also higher in sand culture (6.49\%) than in soil culture $(6.17 \%) . \mathrm{SO}_{4}$ content of leaves was markedly higher in sand culture than in soil culture. The mean $\mathrm{SO}_{4}$ content was 9.72 and $10.88 \%$ in sand culture, but 1.65 and $2.61 \%$ in soil culture, in the $\mathrm{Na}_{2} \mathrm{SO}_{4}$ and $\mathrm{MgSO}_{4}$ series. According to above observations, it is considered that one of the causes which induced the difference of growth between sand and soil cultures is the difference of leaf $\mathrm{Cl}$ or $\mathrm{SO}_{4}$ content.

Meiri et al. (4) have reported that increase in $\mathrm{K}$ ion concentration and decrease in $\mathrm{Ca}$ ion concentration in the sap of bean leaves were more pronounced in sulfate-salinity. Joshi and Naik (3) found that $\mathrm{SO}_{4}$ salts decreased the uptake of $\mathrm{K}$ and $\mathrm{Ca}$ ions in sugarcane. In the present experiment leaf $\mathrm{Ca}$ content was not affected by salinities and not significantly different from the control. $\mathrm{K}$ content of leaves tended to be higher in sodium-salinity and lower in magnesium- 
salinity. These difference between the present experiment and other reports might be due to differences of tested crops, culture regimes, etc..

Several days before harvesting, interveinal chlorosis appeared in sulfate-salinity at -1.70 bars in both sand and soil culture experiments. The symptom may be caused by a combination of the excess $\mathrm{SO}_{4}$ ion or an imbalance of ions induced by the excess $\mathrm{SO}_{4}$ ion, and the stage of green soybeans at which seeds are just swelling and photosynthates and some elements are translocating to the seeds. It is considered that at -1.20 bars $\mathrm{SO}_{4}$ content was not high enough to induce the symptom and at -2.70 bars the plants had not reached that stage. Therefore, interveinal chlorosis might appear only at -1.70 bars.

Soil solutions were centrifugally extracted at $\mathrm{pF} 0$ to 3.8 to explain the difference of growth suppression between two cultures (Tables 4 and 5, Fig. 3). Cation and anion concentrations, EC of the solutions were lower in sand culture, regardless of much more severe growth suppression in sand culture. Questions remain on this point. Therefore, extracting procedures of the soil solutions must be more examined to clarify the mechanism of salt tolerance.

There are several different reports on relationships between plant growth retardation and types of salinity when expressed on an osmotic basis. Meiri et al. (4) have reported that isosmotic concentrations of sodium chloride and sodium sulfate affected the growth of bean plants almost to the same extent. Gauch and Wadleigh(2) have stated the specific Mg toxicity of bean plants, showing very similar amounts of plant growth occurred in the $\mathrm{NaCl}, \mathrm{CaCl}_{2}$ and $\mathrm{Na}_{2} \mathrm{SO}_{4}$ series, but there was marked depression of growth with $\mathrm{MgCl}_{2}$ and $\mathrm{MgSO}_{4}$. Osawa(12) also reported the specific $\mathrm{Mg}$ toxicity of some vegetable crops. Dirr(1) reported that honeylocust was severely injured by exposure to $\mathrm{Cl}$ salts. Joshi and Naik(3) concluded that the degree of toxicity of different ions in decreasing order in sugarcane cv. Co 740 is $\mathrm{SO}_{4}>\mathrm{Na}>\mathrm{Cl}>\mathrm{Mg}$. The result in the present experiment shows that, apart from osmotic effect, $\mathrm{Cl}$ and $\mathrm{SO}_{4}$ have their own effect on the growth of green soybeans. $\mathrm{Cl}$ salts were most deleterious to green soybeans, but $\mathrm{SO}_{4}$, $\mathrm{Na}$ and $\mathrm{Mg}$ salts rarely affected the growth in soil culture. These are similar to the result on honey locust, but do not agree with that of beans and sugarcane. These differences are mainly due to the crops tested and their environments.

\section{Acknowledgement}

Recognition is given Drs. W. J. Clore and $T$. Asahira for their critical reading of this manuscript.

\section{Literature Cited}

1. DIRR, M. A. 1974. Tolerance of honeylocust seedlings to soil-applied salts. HortScience $9: 53-54$.

2. GaUCH, H. G. and C. H. Wadleigh. 1944. Effects of high salt concentrations on growth of bean plants. Bot. Gaz. $105: 379-387$.

3. Joshi, G. V. and G. R. NAIK. 1980. Response of sugarcane to different types of salt stress. Plant and Soil $56: 255-263$.

4. Meiri, A., J. KamburofF and A. PoljakoffMAYBER. 1971. Response of bean plants to sodium chloride and sodium sulphate salinization. Ann. Bot. $35: 837-847$.

5. NUKAYA, A., M. MASUI, A. ISHIDA and T. OGURA. 1977. Salt tolerance of green soybeans. J. Japan. Soc. Hort. Sci. $46: 18-25$.

6. NUKAYA, A., M. MASUI and A. ISHIDA. 1977. Studies on the salt tolerance of muskmelons. V. Relationships between salt tolerance and various salinities. Abstr. Fall Meeting Japan. Soc. Hort. Sci. 1977. 296-297. (In Japanese)

7. NUKAYA, A., M. MASUI and A. ISHIDA. 1978. Studies on the salt tolerance of muskmelons. VI. Relationships between salt tolerance and various salinities in soil culture. Abstr. Spring Meeting Japan. Soc. Hort. Sci. 1978. 278-279. (In Japanese)

8. NUKAYA, A., M. MASUI and A. ISHIDA. 1979. Salt tolerance of tomatoes. J. Japan. Soc. Hort. Sci. $48: 73-81$.

9. NUKAYA, A., M. MASUI and A. ISHIDA. 1980. Salt tolerance of muskmelons grown in different salinity solis. J. Japan. Soc. Hort. Sci. $48: 468-474$.

10. NUKAYA, A., M. Masui and A. IShIDA. 1980. Salt tolerance of muskmelons grown in sand 
and nutrient solution cultures. J. Japan. Soc. Hort. Sci. 49 : 93-101.

11. NukAYA, A., M. MASUI and A. IshidA. 1981. Salt tolerance of green soybeans as affected by various salinities in sand culture. J. Japan. Soc. Hort. Sci. $50: 487-496$.
12. OSAWA, T. 1963. Studies on the salt tolerance of vegetable crops with special reference to osmotic effects and specific ion effects. J. Japan. Soc. Hort. Sci. $32: 211-233$. (In Japanese with English summary)

\section{各種塩類が土耕におけるエダマメの耐塩性に及ぼす影響}

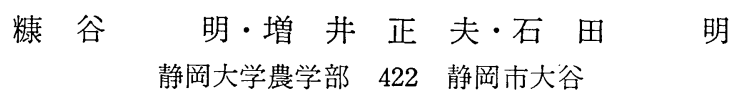

\section{摘 \\ エダマメの耐塩性と塩の種類との関係を明らかにする} ため, 土耕により本実験を行った. 海水, $\mathrm{NaCl}, \mathrm{Na}_{2} \mathrm{SO}_{4}$, $\mathrm{MgCl}_{2}, \mathrm{MgSO}_{4}$ の塩類源をそれぞれ $-1.20,-1.70$ $-2.70 \mathrm{bar}$ とし，生育を基本培盖液（-0.70b ar）で育て た対照区と比較した．海水の-1.20 bar 区, $\mathrm{Na}_{2} \mathrm{SO}_{4}$ の -1.20 と $-1.70 \mathrm{bar}$ 区, $\mathrm{MgSO}_{4}$ の全区の全植物体乾 物重, 種子とさやの新鮮重, 1 箱当たりのさや数は, 対 照区と有意な差がみられなかった。 - $2.70 \mathrm{bar}$ 区に拈け る全乾物重は，対照区を $100 \%$ とした場合，海水で 52.6 $\%, \mathrm{NaCl}$ で $39.6 \%, \mathrm{Na}_{2} \mathrm{SO}_{4}$ で $81.5 \%, \mathrm{MgCl}_{2}$ で 20.4 $\%, \mathrm{MgSO}_{4}$ で8 8.1\%であった. 土耕栽培における生育 は, $\mathrm{MgSO}_{4}$ 及び $\mathrm{Na}_{2} \mathrm{SO}_{4}$ で最大となり, 海水, $\mathrm{NaCl}$,

\section{要}

$\mathrm{MgCl}_{2}$ の順に減少した. $\mathrm{Na}_{2} \mathrm{SO}_{4}$ と $\mathrm{MgSO}_{4}$ では, 収穫 直前の -1.70 bar 区のみに葉脈間クロロシスがみられ た. $\mathrm{Cl}$ 塩処理では, 生育中期の葉にクロロシスとネクロ シスが現れ，次第に上位葉をで進行した。生育後期に は, 特に低い浸透ポテンシャル区においてほとんどの植 物体が枯死した．葉中及び土壤溶液の $\mathrm{Na}, \mathrm{Mg}, \mathrm{Cl}, \mathrm{SO}_{4}$ 含量は，それぞれ $\mathrm{Na}, \mathrm{Mg}, \mathrm{Cl}, \mathrm{SO}_{4}$ を処理した区で，処 理培養液の浸透ポテンシャルが低下するにつれて増加す る傾向がみられた，処理培着液の浸透ポテンシャルが低 下するにつれ，土壤溶液の $\mathrm{EC}$ 值は増加し，浸透ポテン シャルは減少した。 